\title{
A Search for Transmissible Pathogenic \\ Characters in Invasive Strains of Escherichia coli: the Discovery of a Pla smid-controlled Toxin and a Plasmid-controlled Lethal Character Closely Associated, or Identical, with Colicine V
}

\author{
By H. WILLIAMS SMITH \\ Houghton Poultry Research Station, Houghton, Huntingdon PEI 72 DA
}

(Received 22 November 1973; revised I 2 February 1974)

\begin{abstract}
SUMMARY
Most invasive strains of Escherichia coli from man and domestic animals were lethal for chickens and mice. The lethal characteristic was not, in general, transferred when invasive strains were grown in mixed culture with non-pathogenic strains of $E$. coli, although two transmissible plasmids coding for pathogenic properties were discovered.

One plasmid, designated Vir, was found in an $E$. coli strain causing bacteraemia in a lamb. It transferred at high rate to several strains of $E$. coli, including a rec A-KI 2 strain, to Salmonella typhi, Salm. typhimurium and Shigella sonnei. Culture filtrates and, especially, bacterial ultrasonicates of $\mathrm{Vir}^{+}$strains were toxic for chickens, mice and rabbits. The toxin was heat-sensitive, acid-sensitive and non-diffusible. Organisms producing it were agglutinated by specific $\mathrm{Vir}^{+}$ antisera; their toxic activity was not neutralized. The transfer factor of the Vir plasmid was $\mathrm{fi}^{+}$and could transfer antibiotic-resistance determinants in addition to the Vir determinant.

The other plasmid was first discovered in an E. coli strain FI20, isolated from an outbreak of bacteraemia in chickens. Organisms of E. coli $\mathrm{KI} 2$ and of other $E$. coli strains acquiring this plasmid during mixed culture with FI20 were increased in lethality for chickens and mice; this was associated not with toxic activity but with greater ability to survive in blood and peritoneal fluids. Strain FI 20 possessed transmissible ColV and Collb plasmids; increased lethality was closely associated with the ColV plasmid. When the ColV plasmids of another six wild strains of $E$. coli of varied origin were transferred to organisms of $E$. coli $\mathrm{KI}$, the lethality increase was similar to that for Col V transfer from FI 20. No lethality change accompanied transfer of other Col plasmids. It was concluded that colicine $\mathrm{V}$ itself might be responsible for the increased lethality.

Strains of $E$. coli associated with bacteraemia in man and animals commonly produced colicine $\mathrm{V}$.
\end{abstract}

\section{INTRODUCTION}

Several characters possessed by enteropathogenic $E$. coli are controlled by transmissible plasmids. These include the production of enterotoxin (Smith \& Halls, I968; Smith \& Linggood, I97I, 1972; Skerman, Formal \& Falkow, 1972), K88 antigen (Ørskov \& Ørskov, I966), K99 antigen (Smith \& Linggood, 1972) and $\alpha$-haemolysin (Smith \& Halls, 1967). Whereas enteropathogenic strains of $E$. coli are usually confined to the alimentary tract, other pathogenic strains are invasive and produce their harmful effects in other tissues. It seemed worth determining whether any of the properties peculiar to invasive strains were also plasmid-controlled.

The main approach to the problem was to grow invasive strains of $E$. coli in mixed culture 
with non-pathogenic strains under conditions providing maximum opportunity for conjugation, and then to determine whether the non-pathogenic strains had become lethal for chickens and mice.

Most of the invasive strains produced a fatal bacteraemia when administered parenterally. No transmissible genetic element was demonstrated for the bacteraemic character of the invasive strains, but a toxin in one of two strains that produced it was controlled by a transmissible plasmid. Also, the production of colicine $\mathrm{V}$, a common feature of invasive strains, was associated with increased lethality. Although, perhaps, not strictly invasive, some E. coli strains isolated from cases of cystitis and ulcerative colitis were also examined.

\section{METHODS}

Experimental animals. Specified pathogen-free Light Sussex chickens were employed. Unless otherwise stated, they were $3 \frac{1}{2}$ weeks old and weighed approximately $300 \mathrm{~g}$ when put under experiment. The mice were young adults of the White Swiss breed (Tuck TO) and the rabbits were New Zealand Whites. All the animals were fed ad libitum on commercial diets not containing antibiotics.

E. coli strains. The invasive strains had been isolated from man and animals under conditions strongly suggesting a pathogenic role. The majority of the animal strains had been isolated in this laboratory; the others were received from Drs Mary Cooke, F. and I. Ørskov, B. Rowe, R. Sakarzaki and W. J. Sojka. Apart from E. coli KI 2, all the strains classed as non-pathogenic had been isolated from the faeces of healthy men (prefix $\mathrm{H}$ ), pigs (prefix P) or sheep (prefix S); the antigenic formula of strain $\mathrm{H}_{20} 09$ was $\mathrm{O}_{9}$; $\mathrm{K}_{3} \mathrm{I}$; H 44 and that of SI was $\mathrm{O}_{7} 8 ; \mathrm{K} 80$. All strains were maintained on Dorset egg medium at $5{ }^{\circ} \mathrm{C}$.

Culture media and cultural conditions. Nutrient broth contained (g/l): Oxoid 'Lab. Lemco' I0; Oxoid peptone, $\mathrm{L} 37, \mathrm{I}$; glucose, $\mathrm{I} ; \mathrm{NaCl}, 5$. Its $\mathrm{pH}$ was adjusted to 7.5 before autoclaving at $105^{\circ} \mathrm{C}$ for $20 \mathrm{~min}$. Except where stated, broth cultures consisted of organisms grown in $10 \mathrm{ml}$ broth for $24 \mathrm{~h}$ in a shaking water bath at $37^{\circ} \mathrm{C}$; they contained approximately $\mathrm{I} \cdot 5 \times 10^{9}$ viable organisms $/ \mathrm{ml}$. The addition of $0.36 \%$ agar to nutrient broth constituted soft agar. All cultures in this medium were incubated at $37^{\circ} \mathrm{C}$ for $24 \mathrm{~h}$, after which the bacteria and fluids were expressed through muslin by gentle squeezing; the fluids contained approximately $6.0 \times 10^{9}$ viable organisms $/ \mathrm{ml}$.

Determination of lethality of strains of E. coli for experimental animals. Unless otherwise stated, broth cultures were injected intravenously (i.v.) into chickens in $0.3 \mathrm{ml}$ amounts $\left(5 \times 10^{8}\right.$ viable organisms) and intraperitoneally (i.p.) into mice in $0.05 \mathrm{ml}$ amounts $\left(7.5 \times 10^{7}\right.$ viable organisms). The animals were observed daily for 4 days and the livers of those that died were cultured on MacConkey agar to confirm recovery of inoculum organisms.

Transfer of lethal characters. Nutrient broth was seeded with $0.02 \mathrm{ml}$ volumes of broth cultures of a lethal strain of $E$. coli and of a streptomycin-resistant mutant of a non-lethal strain - the prospective recipient. The mixed culture was incubated at $37{ }^{\circ} \mathrm{C}$ for $48 \mathrm{~h}$ without shaking and $0.2 \mathrm{ml}$ inoculated into broth containing $30 \mu \mathrm{g}$ streptomycin sulphate $/ \mathrm{ml}$. After incubation at $37^{\circ} \mathrm{C}$ for $24 \mathrm{~h}, 0.2 \mathrm{ml}$ of the culture with streptomycin was inoculated into more streptomycin-containing broth, the latter incubated as before and then sub-cultured into plain broth. This culture, referred to as the passaged mating culture, was then examined to confirm, as far as possible, that it did not contain donor organisms. For this purpose, and whenever it was necessary to distinguish donor from recipient strains, differences in their growth characteristics, antibiotic sensitivity or antigenic structure were exploited; some of the recipients were $l a c^{-}$and others were mutants resistant to nalidixic 
acid, spectinomycin or ampicillin in addition to streptomycin. If no donor organisms were found in the passaged mating culture, $0.5 \mathrm{ml}$ was injected i.v. into a chicken and, if the chicken died, its liver was cultured to test that only organisms of the recipient strain were present. If so, the same lethality test was repeated in at least three animals and, if the result was still positive, the passaged mating culture was inoculated onto MacConkey agar to give well-separated colonies on incubation. A number of these colonies was purified by replating and then tested for lethality.

Occasionally, the above procedure was varied. For example, if the donor strain was itself streptomycin-resistant, an ampicillin-resistant or nalidixic acid-resistant mutant of the recipient strain was employed; the mating culture was then passaged through broth containing $30 \mu \mathrm{g}$ ampicillin or sodium nalidixate $/ \mathrm{ml}$. Also, if the donor strain possessed an $\mathrm{R}$ factor, the mating culture was sometimes passaged through broth containing one of the antibiotics to which the donor strain was resistant in addition to the antibiotic to which the recipient was resistant.

Colicines. These were identified by the method of Lewis (I968) using the indicator and colicine-producing strains of Professor P. Fredericq of the University of Liege; final identification of the colicines produced by all the bacterial strains employed in comparative lethality tests was achieved by Professor Fredericq himself.

The identification of bacterial strains possessing transfer factors. This was performed by the antibiotic resistance determinant-mobilization test (Anderson, 1965) as described by Smith \& Linggood (1970), the presence of a transfer factor being identified by its ability to mobilize a streptomycin/sulphonamide resistance determinant in an E. coli KI 2 strain.

Fertility-inhibiting $(f i)$ character of transfer factors. This was determined by transmitting an F-linked tetracycline-resistance determinant from an $E$. coli KI 2 strain to another KI 2 strain possessing the transfer factor under test. The latter strain was then examined for susceptibility to visible lysis by the F-specific phage MS2 (Davis, Strauss \& Sinsheimer, I961).

The estimation of $\mathrm{Col} \mathrm{V}^{+}$and $\mathrm{Col} V^{-}$organisms in the blood and liver of chickens and in the blood and peritoneal washings of mice. Chickens were injected i.v. with equal numbers of washed $\mathrm{Col} \mathrm{V}^{+}$or $\mathrm{Col} \mathrm{V}^{-}$organisms of the same strain of $E$. coli. At intervals viable numbers were estimated in blood removed from wing veins. Viable numbers in the liver were estimated on I $g$ organ samples removed at the end of the experiment and ground with sterile sand and $9 \mathrm{ml}$ volumes of phosphate buffer $(\mathrm{pH} 7 \cdot 0)$ in a pestle and mortar. Some chickens were infected with equal numbers of both $\mathrm{Col} \mathrm{V}^{+}$and $\mathrm{Col} \mathrm{V}^{-}$organisms. Colonies from blood and liver samples of these chickens were spot-inoculated directly onto Petri plates of nutrient agar over which had been spread a diluted culture of $E$. coli K 2 to differentiate the $\mathrm{ColV}^{+}$from the $\mathrm{ColV}^{-}$colonies. When colicine V-resistant (col $\mathrm{V}^{\mathrm{r}}$ ) organisms were included in the mixed inoculum given to chickens, their colonies were differentiated from those of $\mathrm{Col} \mathrm{V}^{+}$and $\mathrm{Col} \mathrm{V}^{-}$ones by their insusceptibility to colicine $\mathrm{V}$ and inability to produce it. Mice were also injected i.p. with equal numbers of washed $\mathrm{Col} \mathrm{V}^{+}$ or $\mathrm{ColV}^{-}$organisms of the same strain, killed $18 \mathrm{~h}$ later, and viable numbers estimated in heart blood and washings rinsed from the peritoneal cavity with $\mathrm{I} \mathrm{ml}$ saline. Colonies obtained from mice infected with equal numbers of both $\mathrm{Col} \mathrm{V}^{+}$and $\mathrm{ColV}^{-}$organisms were differentiated as those from infected chickens.

The survival of $\mathrm{ColV}^{+}$and $\mathrm{ColV}^{-}$organisms in chicken serum. Broth cultures of $\mathrm{Col} \mathrm{V}^{+}$ and $\mathrm{ColV}^{-}$organisms of the same strain of $E$. coli were diluted I in 20000 in phosphate buffer, and $0.08 \mathrm{ml}$ volumes added to $0.5 \mathrm{ml}$ volumes of chicken serum and incubated in a shaking water bath at $37^{\circ} \mathrm{C}$. At intervals, viable numbers were estimated. Sometimes both kinds of organisms were added to the same sample of chicken serum. In this case, 
Table I. The lethality for chickens and mice of strains of $E$. coli from different sources

Chickens received $0.3 \mathrm{ml}$ volumes of a broth culture intravenously, and mice $0.05 \mathrm{ml}$ intraperitoneally.

\begin{tabular}{|c|c|c|c|c|}
\hline \multicolumn{2}{|c|}{ Source of $E$. coli } & \multirow{2}{*}{$\begin{array}{l}\text { No. strains } \\
\text { tested }\end{array}$} & \multicolumn{2}{|c|}{ No. lethal for: } \\
\hline Host & Clinical condition & & Chickens & Mice \\
\hline Man & $\begin{array}{l}\text { Bacteraemia or meningitis } \\
\text { Cystitis } \\
\text { Ulcerative colitis } \\
\text { Neonatal diarrhoea }\end{array}$ & $\begin{array}{r}45 \\
9 \\
19 \\
19\end{array}$ & $\begin{array}{r}27 \\
5 \\
8 \\
2\end{array}$ & $\begin{array}{r}36 \\
7 \\
9 \\
-\end{array}$ \\
\hline Chickens & Bacteraemia & 40 & 39 & - \\
\hline Calves and lambs & $\begin{array}{l}\text { Bacteraemia } \\
\text { Neonatal diarrhoea }\end{array}$ & $\begin{array}{r}14 \\
7\end{array}$ & $\begin{array}{r}13 \\
0\end{array}$ & - \\
\hline Pigs & $\begin{array}{l}\text { Neonatal and post-weaning } \\
\text { diarrhoea }\end{array}$ & 12 & 2 & - \\
\hline $\begin{array}{l}\text { Man, chickens and } \\
\text { pigs }\end{array}$ & $\begin{array}{l}\text { None* } \\
\text { olated from the faeces of he }\end{array}$ & $\begin{array}{l}\text { I4 } \\
\text { ndividuals. }\end{array}$ & 2 & - \\
\hline
\end{tabular}

50 colonies from each of two sets of viable-count plates were examined for colicine production as previously described. The first set were those of organisms present in the serum sample at the commencement of the experiment, and the second set were those prepared when the number of viable organisms in the sample had been reduced by 90 to $95 \%$. In control tests, samples of sera were heated at $65^{\circ} \mathrm{C}$ for $30 \mathrm{~min}$ before inoculation to confirm that the serum could support the multiplication of $\mathrm{ColV}^{+}$and $\mathrm{ColV}^{-}$organisms.

Bacterial counts. Viable organisms in broth cultures and tissue fluids were estimated by the method of Miles \& Misra (1938) using MacConkey's agar.

Antisera. These were prepared by the multiple i.v. injection of rabbits with live broth cultures.

Statistical analysis. The results of lethality tests were analysed in $2 \times 2$ contingency tables and examined for significance by the $\chi^{2}$ test by Mr J. G. Rowell of the A.R.C. Statistics Group at Cambridge University.

\section{RESULTS}

The lethality for chickens and mice of strains of E. coli from different sources

Chickens were inoculated intravenously and mice intraperitoneally with strains of $E$. coli associated with different disease conditions in man and domestic animals (Table I). All except two of the 54 strains isolated from animals with bacteraemia were lethal for chickens and so were over half of the strains from human beings with bacteraemia, meningitis, ulcerative colitis or cystitis; a slightly higher proportion of the human strains were lethal for mice. By contrast, of the strains isolated from the faeces of human beings or animals - whether healthy or suffering from $E$. coli diarrhoea - only a small proportion were lethal for chickens. In the chickens and mice that died in these experiments, death usually occurred within I to 2 days of infection and, at autopsy, large numbers of organisms of the infecting strain were cultured from their livers. Supernatant fluids of centrifuged broth cultures of the lethal human strains were injected i.v. into chickens in $\mathrm{I} \cdot 0 \mathrm{ml}$ amounts and into mice in $0.2 \mathrm{ml}$ amounts; none of the animals died. 
Table 2. The incidence of transfer factors in invasive strains of E. coli

$\begin{array}{lcc}\begin{array}{c}\text { Source of } \\ \text { strains }\end{array} & \begin{array}{c}\text { No. } \\ \text { examined }\end{array} & \begin{array}{c}\text { Percentage } \\ \text { with } \\ \text { transfer } \\ \text { factors }\end{array} \\ \text { Calves and lambs } & \text { I8 } & 78 \\ \text { Chickens } & 65 & 43 \\ \text { Human beings } & 45 & 9\end{array}$

Table 3. The rate of transfer of the Vir plasmid from E. coli $\mathrm{S}_{5}$ to different recipient strains

$\begin{array}{lcc}\text { Necipient strain } & \begin{array}{c}\text { Colonies of recipient } \\ \text { strains from a mating } \\ \text { with s5 }\end{array} \\ \text { E. coli } \mathrm{KI} \text { 2 } & 32 & 37 \\ \text { E. coli } \mathrm{K12recA} & 30 & 30 \\ \text { E. coli } \mathrm{H} 209 & 102 & 14 \\ \text { E. coli } \mathrm{H} 209 \mathrm{~K}+ & 13 & 100 \\ \text { E. coli } \mathrm{HIO3} & 20 & 25 \\ \text { Shigella } \text { Sonnei } & 20 & 60 \\ \text { Salmonella typhimurium } & 24 & 17\end{array}$

* Assessed by lethality for chickens (I/colony tested) of approx. $5 \times 10^{8}$ viable organisms i.v. from broth cultures grown from single colonies of recipients. Only those broth cultures of Salm. typhimurium that produced lesions characteristic of Vir activity were recorded as $\mathrm{Vir}^{+}$.

$+\mathrm{K}$ antigen lost.

The incidence of transfer factors in invasive strains of $E$. coli

E. coli strains associated with bacteraemia, cystitis and ulcerative colitis in man and bacteraemia in calves, lambs and chickens were examined for transfer factors (Table 2); none of these strains possessed characters known to be transferable, such as antibiotic resistance and colicine and haemolysin production. Transfer factors were common in the animal strains, being five times more frequent in chicken and nine times more frequent in calf and lamb strains than in the human strains.

\section{The transfer of lethality from invasive strains of E. coli to non-lethal strains}

In all, 550 passaged mating cultures were tested for lethality in chickens. These were derived from one or other of five recipient strains of $E$. coli that had been grown in mixed culture with one or other of 200 potential donor strains that were lethal for chickens and that had originated from human beings (40), calves and lambs (20), and chickens (140). The five recipient strains, $\mathrm{KI}_{2}, \mathrm{PI}_{3}, \mathrm{H}_{2} 09, \mathrm{HI} \mathrm{O}_{3}$ and SI, were chosen for use principally because they were good recipients of $\mathrm{R}$ factors, did not possess transfer factors and were always non-lethal under the conditions of test; if employed in increased dosage and/or in 2-weekold (instead of $3 \frac{1}{2}$-week-old) chickens, some strains exhibited a low degree of lethality (see Table 6 for example). During culture in broth, strain $\mathrm{H} 209$ usually gave rise to $\mathrm{K}$ - variants so that passaged mating cultures of this strain consisted of mixtures of $\mathrm{K}^{+}$and $\mathrm{K}^{-}$organisms. The only chickens that died were those given passaged mating cultures grown with either of two of the 200 potential donor strains. Subsequent investigations, described below, indicated that these two strains possessed transmissible plasmids coding for lethal 
characters. One of the plasmids was provisionally designated Vir, while the other, on account of its close association with colicine $\mathrm{V}$ production, was not named.

\section{The Vir plasmid}

Strain 55 (antigenic formula $\mathrm{O}_{15}: \mathrm{K}$ ?:H21), the $E$. coli strain possessing the Vir plasmid, had been isolated from the blood of a lamb that had died from an $E$. coli bacteraemia. The presence of the plasmid was first suspected when the passaged mating culture of the recipient strain $\mathrm{H}_{209}$ grown with 55 proved lethal for chickens. A further eight matings between these two strains all gave rise to passaged mating cultures of $\mathrm{H} 209$ that were chicken-lethal. The examination of single colonies from one passaged mating culture and from matings of

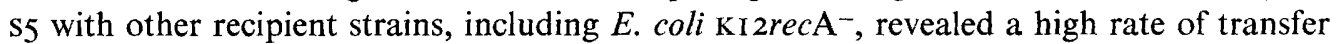
of lethal activity, the highest rate being to $\mathrm{K}^{-}$organisms of $\mathrm{H} 209$ (Table 3). Unlike other recipients, the Salmonella typhimurium strain was lethal for chickens. However, its $\mathrm{Vir}^{+}$ forms could be distinguished from $\mathrm{Vir}^{-}$forms by the characteristic lesions $\mathrm{Vir}^{+}$organisms produced in chickens (see below).

Vir transfer was not detected during culture of a $\mathrm{H}_{209 \mathrm{~K}^{-}}$strain in broth containing $5 \mathrm{ml}$ of a membrane filtrate (Millipore; $450 \mathrm{~nm}$ ) of a broth culture of strain s5. The latter was not latently infected with bacterial viruses active on $\mathrm{H} 209, E$. coli $\mathrm{KI} 2$ or any of the other strains tested. It possessed an $\mathrm{fi}^{+}$transfer factor (Tra) detected by antibiotic resistance determinant mobilization tests in all of five $\mathrm{Vir}^{+}$strains of $\mathrm{H} 209$ obtained from a mating with $\mathrm{s} 5$ but not in five $\mathrm{Vir}^{-}$strains obtained from the same mating; four $\mathrm{Vir}^{+}$and four $\mathrm{Vir}^{-}$strains of Salm. typhimurium obtained in a similar manner were $\mathrm{Tra}^{+}$and $\mathrm{Tra}^{-}$respectively, as were $\mathrm{I}_{2} \mathrm{Vir}^{+}$ and $20 \mathrm{Vir}^{-}$strains of $E$. coli $\mathrm{KI} 2$. Vir- forms were not detected in a $\mathrm{H}_{2} \mathrm{O} 9 \mathrm{Vir}^{+}$strain during acridine orange treatment. $\mathrm{Vir}^{-}$forms of Salm. typhimurium, however, were found in the tissues of chickens inoculated with $\mathrm{Vir}^{+-}$organisms of this strain.

\section{Serological studies on Vir $^{+}$bacteria}

Antisera were prepared against $E$. coli $\mathrm{S} 5$ and against $\mathrm{Vir}^{+}$and $\mathrm{Vir}^{-}$forms of $E$. coli $\mathrm{H} 209$ and $\mathrm{H}_{209 \mathrm{~K}^{-}}$, those prepared against the $\mathrm{Vir}^{+}$forms of $\mathrm{H} 209$ and $\mathrm{H}_{209 \mathrm{~K}^{-}}$being subsequently absorbed with live organisms of the corresponding Vir-- forms. Slide tests with these antisera revealed that $\mathrm{S} 5$, and the $\mathrm{Vir}^{+}$but not the $\mathrm{Vir}^{-}$forms of $\mathrm{H}_{2} \mathrm{O} 9$ and $\mathrm{H}_{209 \mathrm{~K}^{-}}$, possessed a common antigen. In these tests, bacterial suspensions that had been held at $60{ }^{\circ} \mathrm{C}$ for $30 \mathrm{~min}$ agglutinated more slowly than live suspensions; suspensions held at $100{ }^{\circ} \mathrm{C}$ for $30 \mathrm{~min}$ did not agglutinate. The antigen was also demonstrated in all of $\mathrm{I}_{4} \mathrm{Vir}^{+}$strains of $\mathrm{H}_{209}$ or $\mathrm{H}_{209} \mathrm{~K}^{-}$obtained from several matings with $\mathrm{s} 5$ but not in any of eight $\mathrm{Vir}^{-}$strains obtained from these matings. From other matings, all of four strains of Salmonella typhimurium, I 2 strains of Shigella sonnei and five strains of E. coli HIO3, all classed as $\mathrm{Vir}^{+}$by lethality tests, possessed the antigen whereas all of four strains of Salm. typhimurium, eight strains of Sh. sonnei and 15 strains of HIO3 classed as Vir ${ }^{-}$did not.

Because of the complete correlation found between lethality and agglutination tests, subsequent attempts to transfer Vir were monitored by the slide agglutination test. Vir was transferred to a chicken bacteraemia strain of E. coli $\left(\mathrm{O}_{2}: \mathrm{Kr}\right)$ and to $\mathrm{Vi}^{+}$and $\mathrm{Vi}^{-}$forms of Salmonella typhi, $\mathrm{Vir}^{+}$colonies derived from the $\mathrm{Vi}^{+}$form agglutinating poorly with $\mathrm{Vi}^{+}$ antiserum. Transfer to the $E$. coli strain was confirmed by lethality tests; these tests were not performed for the Salm. typhi strain. Transfer was not detected to 12 strains of $E$. coli enteropathogenic for man, calves or pigs, to three chicken bacteraemia strains, to three strains of Shigella flexneri or to one strain each of Salm. dublin, Salm. cholerae-suis, Salm. pullorum, Proteus rettgeri, Proteus mirabilis and Pseudomonas aeruginosa. 
Table 4. The lethality for chickens, rabbits and mice of filtrates and ultrasonicates of broth cultures of $\mathrm{Vir}^{+}$and $\mathrm{Vir}^{-}$forms of $\mathrm{E}$. coli $\mathrm{H} 209 \mathrm{~K}^{-}$

\begin{tabular}{|c|c|c|c|c|c|}
\hline \multirow{2}{*}{$\begin{array}{c}\text { Forms of } \\
\mathrm{H} 209 \mathrm{~K}^{-}\end{array}$} & \multirow{2}{*}{$\begin{array}{c}\text { Material } \\
\text { injected i.v. }\end{array}$} & \multirow{2}{*}{$\begin{array}{l}\text { Dose } \\
(\mathrm{ml})\end{array}$} & \multicolumn{3}{|c|}{ No. died $/$ no. injected } \\
\hline & & & Chickens & Rabbits & Mice \\
\hline \multirow[t]{13}{*}{ Vir $^{+}$} & Culture filtrate & $5 \cdot 0$ & $\ldots$ & $0: 2$ & - \\
\hline & & 0.4 & $3: 3$ & - & $0: 8$ \\
\hline & & 0.2 & $1 / 3$ & - & - \\
\hline & & 0.1 & $0 / 3$ & - & 一 \\
\hline & Ultrasonicate & 0.8 & - & $2 / 2$ & - \\
\hline & & 0.4 & - & $1 / 3$ & $\mathrm{I} / \mathrm{I}$ \\
\hline & & $0 . I$ & 一 & - & $3 / 3$ \\
\hline & & 0.05 & $3 / 3$ & - & $0 ; 3$ \\
\hline & & 0.025 & 33 & - & - \\
\hline & & 0.012 & $3 / 3$ & - & - \\
\hline & & 0.006 & $5 / 6$ & - & - \\
\hline & & 0.003 & $1 / 3$ & - & $\ldots$ \\
\hline & & 0.002 & $0 / 3$ & - & - \\
\hline \multirow[t]{4}{*}{ Vir- } & Culture filtrate & $5 \cdot 0$ & $0: 2$ & - & - \\
\hline & Ultrasonicate & $5 \cdot 0$ & $0: 3$ & $0: 2$ & - \\
\hline & & $1 \cdot 0$ & $0 / 3$ & - & - \\
\hline & & 0.4 & - & - & $0 / 3$ \\
\hline
\end{tabular}

Culture filtrates were membrane-sterilized supernatants from centrifuged broth cultures; ultrasonicates were membrane-sterilized supernatants from broth cultures centrifuged after ultrasonic treatment (M.S.E., IO० W, $3 / 4$ in probe for $5 \mathrm{~min}$ with cooling).

The incidence of Vir activity in strains of E. coli

By slide agglutination tests, the Vir antigen was detected in only one of I 90 epidemiologically-unrelated human (50), bovine (74), ovine (38) and porcine (28) strains of E. coli; these strains had been isolated from the faeces of healthy individuals or from cases of diarrhoea or bacteraemia. The one $\mathrm{Vir}^{+}$strain, like $\mathrm{s5}$, had been isolated from the blood of a lamb suffering from $E$. coli bacteraemia. It had the same antigenic formula as $E$. coli $\mathrm{S} 5$ and produced lesions typical of Vir activity when inoculated into chickens. Although it possessed a transfer factor, all attempts to transfer its Vir activity failed.

\section{The lethality for chickens, rabbits and mice of filtrates and ultrasonicates of broth cultures of $\mathrm{Vir}^{+}$and $\mathrm{Vir}^{-}$organisms}

Different amounts of sterile membrane filtrates and ultrasonicates of broth cultures of

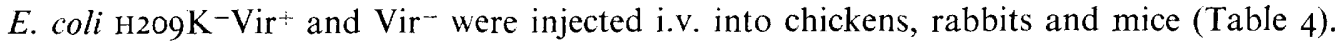
The filtrates and ultrasonicates of the Vir- culture produced no ill effect. By contrast, both preparations from the $\mathrm{Vir}^{+}$culture were lethal - especially the ultrasonicates; chickens were more susceptible than rabbits and mice. Two groups of three chickens given $0.4 \mathrm{ml}$ of the Vir ${ }^{+}$ultrasonicate i.p. or i.m. died; a group given $5^{\circ} \mathrm{o} \mathrm{ml}$ orally remained well.

Results similar to those above were obtained with $\mathrm{Vir}^{+}$and $\mathrm{Vir}^{-}$forms of other strains, provided similar cultural conditions were employed; in conditions of partial or strict anaerobiosis, no toxic effect was detected. Live cultures, culture filtrates and ultrasonicates of all the $\mathrm{Vir}^{+}$strains produced the same syndrome when injected i.v. into chickens, rabbits and mice. Depending on the dose, death occurred within 6 to $24 \mathrm{~h}$. Always present in dead chickens were large amounts of clear yellow serous fluid in the abdominal cavity and pericardial sac, and characteristically pale-coloured livers. Pale livers were common, too, in the dead rabbits and mice, but not the excess fluid. The livers of four chickens, one 
Table 5. The effect of temperature and $\mathrm{pH}$ on lethality for chickens of filtrates of a broth culture of E. coli $\mathrm{H} 209 \mathrm{~K}^{-} \mathrm{Vir}^{+}$

\begin{tabular}{|c|c|c|c|}
\hline $\begin{array}{c}\text { Filtrate } \\
\text { temperature* } \\
\left({ }^{\circ} \mathrm{C}\right)\end{array}$ & $\begin{array}{c}\text { Lethality } \\
\text { of } \\
\text { filtrate* }\end{array}$ & $\begin{array}{c}\text { Filtrate } \\
\mathrm{pH} \dagger\end{array}$ & $\begin{array}{c}\text { Lethality } \\
\text { of } \\
\text { filtrate }\end{array}$ \\
\hline $100 \cdot 0$ & $0 / 3$ & 10.0 & $3 / 3$ \\
\hline $80 \cdot 0$ & $0 / 3$ & $9 \cdot 0$ & $5 / 5$ \\
\hline $60 \cdot 0$ & $0 / 9$ & 8.0 & $2 / 2$ \\
\hline $57 \cdot 5$ & $0 / 8$ & $7 \cdot 0$ & $10 / 10$ \\
\hline $55^{\circ}$ & $0 / 8$ & 6.0 & $2 / 2$ \\
\hline $52 \cdot 5$ & O/I I & 5.0 & $0 / 9$ \\
\hline $50 \cdot 0$ & $0 / 13$ & 40 & $0 / 3$ \\
\hline $47 \cdot 5$ & $2 / 5$ & - & - \\
\hline $45^{\circ} \circ$ & $12 / 13$ & - & - \\
\hline 37.0 & $8 / 8$ & - & $\ldots$ \\
\hline
\end{tabular}

mouse and one rabbit were examined histologically by $\mathrm{Dr}$ J. E. T. Jones, who reported that the main lesion present was focal necrosis of the liver cells with, in the case of the chicken livers, a pronounced and widespread distension of the sinusoids with erythrocytes.

The effect of heat, $\mathrm{pH}$ and dialysis on the lethality of filtrates and ultrasonicates of $\mathrm{Vir}^{+}$cultures

Broth culture filtrates of $E$. coli $\mathrm{H}_{20} \mathrm{O} \mathrm{K}^{-} \mathrm{Vir}^{+}$were held at different temperatures and $\mathrm{pH}$ values and then injected i.v. into chickens (Table 5). Holding at $50{ }^{\circ} \mathrm{C}$ or more for $30 \mathrm{~min}$, or at $\mathrm{pH} 5.0$ or lower for $\mathrm{I} h$, rendered the filtrate innocuous. Similar results were obtained with sterile ultrasonicates of broth cultures of this strain.

Using Visking seamless cellulose tubing, $20 \mathrm{ml}$ of a broth culture filtrate of $\mathrm{H}_{209} \mathrm{~K}^{-} \mathrm{Vir}^{-}$ were dialysed against $20 \mathrm{ml}$ of broth for 2 days. Two chickens were then injected i.v. with $2.0 \mathrm{ml}$ volumes of the diffusate; both remained well. Dialysis was continued for a further day against I 1 broth, and $0.2 \mathrm{ml}$ volumes of the dialysate were then injected i.v. into two chickens. Both died, indicating that little or none of the filtrate toxicity had been lost during dialysis.

\section{The effect of antiserum on Vir activity}

Broth culture filtrates of E. coli $\mathrm{H} 209 \mathrm{~K}^{-} \mathrm{Vir}^{+}$in $0.4 \mathrm{ml}$ amounts were incubated at $37^{\circ} \mathrm{C}$ for I to $3 \mathrm{~h}$ with 0.4 to $2.0 \mathrm{ml}$ volumes of an antiserum against live broth cultures of this strain, and the mixtures then injected i.v. into four chickens; all four died, exhibiting lesions characteristic of Vir activity. Similarly, failure of antiserum protection was noted with sterile ultrasonicates in chickens $(0.02 \mathrm{ml}$ ultrasonicate +0.4 to $2.0 \mathrm{ml}$ antiserum) and in mice $(0.2 \mathrm{ml}$ ultrasonicate +0.2 to $0.4 \mathrm{ml}$ antiserum).

The influence of the Vir plasmid on the pathogenicity of Salm. typhimurium for chickens

Two groups of 25 one-day-old chickens were given orally $0.5 \mathrm{ml}$ of a broth culture of either a $\mathrm{Vir}^{+}$or a $\mathrm{Vir}^{-}$form of Salm. typhimurium. Very little difference was noted in the course of the disease between the two groups: by the sixth day after infection, 22 chickens in the $\mathrm{Vir}^{+}$group and $\mathrm{I} 8$ in the $\mathrm{Vir}^{-}$group had died; the results of i.p. administration of 
Table 6. The lethality for chickens of strains of E. coli possessing different combinations of the Col $V$ and $I b$ plasmids of E. coli FI 20

\begin{tabular}{|c|c|c|c|}
\hline Strain tested & Origin of its plasmids & $\begin{array}{l}\text { No. of } \\
\text { chickens } \\
\text { injected* }\end{array}$ & $\begin{array}{c}\text { Percentage } \\
\text { of chicken } \\
\text { deaths }\end{array}$ \\
\hline $\mathrm{H} 209 \mathrm{Col} \mathrm{V}^{+} \mathrm{Ib}^{+}$ & 2nd mating with FI 20 & 70 & 61 \\
\hline $\mathrm{H} 209 \mathrm{Col} \mathrm{V}^{+}$ & Ist mating with FI 20 & I 18 & 59 \\
\hline $\mathrm{H} 209 \mathrm{Col} \mathrm{V}^{+}$ & 3rd mating with FI 20 & 37 & $5 \mathbf{I}$ \\
\hline $\mathrm{H} 209 \mathrm{Col} \mathrm{V}^{+}$ & $\begin{array}{l}\text { Mating with } E \text {. coli K I } 2 \mathrm{Col} \mathrm{V}^{+} \text {whose } \mathrm{Col} \mathrm{V} \\
\text { plasmid had been acquired from FI } 20\end{array}$ & 25 & 52 \\
\hline $\mathrm{H} 209 \mathrm{Col} \mathrm{Ib}$ & Ist mating with Fi 20 & 30 & 13 \\
\hline $\mathrm{H} 209 \mathrm{Col} \mathrm{Ib}$ & 3rd mating with F120 & 37 & 16 \\
\hline $\begin{array}{l}\mathrm{H} 209 \mathrm{Col} \mathrm{V}^{-} \\
\left(\mathrm{Col} \mathrm{V}^{+}\right)\end{array}$ & $\begin{array}{l}\text { Ist mating with FI } 20 \text {, Col V plasmid acquired } \\
\text { then lost }\end{array}$ & 70 & 10 \\
\hline $\mathrm{H} 209 \mathrm{Col}^{-}$ & Ist mating with F I 20, no Col plasmids acquired & 92 & 10 \\
\hline $\mathrm{H} 209 \mathrm{Col}^{-}$ & 2nd mating with FI 20 , no Col plasmids acquired & 30 & 7 \\
\hline PIO Col V+ $\mathrm{Ib}^{+}$ & Mating with FI 20 & 30 & 100 \\
\hline PIo Col $\mathrm{Ib}^{+}$ & Mating with FI 20 & 30 & 3 \\
\hline Plo Col"- & Mating with FI 20 , no Col plasmids acquired & 30 & 3 \\
\hline $\mathrm{KI} 2 \mathrm{Col} \mathrm{V}+\mathrm{Ib}^{+}$ & $\begin{array}{l}\text { Mating with PIo Col } \mathrm{V}^{+} \mathrm{Ib}^{+} \text {whose Col plasmids } \\
\text { had been acquired from FI } 20\end{array}$ & 30 & 80 \\
\hline $\mathrm{KI} 2 \mathrm{Col} \mathrm{V}+$ & Mating with FI 20 & 22 & 86 \\
\hline $\mathrm{K} I 2 \mathrm{Col} \mathrm{V+}$ & $\begin{array}{l}\text { Mating with } \mathrm{H}_{20} \mathrm{O} \mathrm{Col} \mathrm{V}^{+} \text {whose Col V plasmid } \\
\text { had been acquired from FI } 20\end{array}$ & I IO & 87 \\
\hline $\mathrm{K} 12 \mathrm{Col} \mathrm{V}^{+}$ & $\begin{array}{l}\text { 6th successive transfer of Col V plasmid between } \\
\text { strains of KI } 2\end{array}$ & 30 & 73 \\
\hline KI 2 Col Ib & $\begin{array}{l}\text { Mating with } \mathrm{H} 209 \mathrm{Col} \mathrm{Ib}^{+} \text {whose Ib plasmid } \\
\text { had been acquired from FI } 20\end{array}$ & 30 & 7 \\
\hline KI2 Tra ${ }^{+}$ & $\begin{array}{l}\text { Mating with } \mathrm{H} 209 \mathrm{Col} \mathrm{V}^{+} \text {(transfer factor } \\
\text { acquired) }\end{array}$ & 30 & 15 \\
\hline $\mathrm{KI} 2 \mathrm{Col}^{-}$ & Unmated recipient strain & 148 & 7 \\
\hline
\end{tabular}

* Two-week-old chickens received i.v. $7.5 \times 10^{8}$ viable organisms from broth cultures of the $\mathbf{H} 209$ strains or $3.0 \times 10^{9}$ viable organisms from soft agar cultures of the PIO and $\mathrm{K} I 2$ strains.

$\mathrm{Vir}^{+}$and $\mathrm{Vir}^{-}$cultures to three-day-old chickens were also similar. About half of the Salm. typhimurium organisms isolated from dead chickens given the $\mathrm{Vir}^{+}$form had lost the Vir plasmid.

\section{The Col $V$ plasmid}

The discovery that a plasmid coding for colicine $\mathrm{V}$ production was associated with lethality stemmed from an observation that all of four different passaged mating cultures of $E$. coli $\mathrm{H} 209$ that had been grown with an $\mathrm{O}_{78}: \mathrm{K} 80$ strain of $E$. coli, FI20, were lethal for chickens on i.v. injection. E. coli FI20, which had been associated with an outbreak of bacteraemia in broiler chickens, produced two colicines, $\mathrm{Ib}$ and $\mathrm{V}$. Both colicines were controlled by transmissible plasmids which transferred at a high rate from FI 20 to E. coli $\mathrm{H} 209$ and $\mathrm{KI} 2$; the exconjugants had acquired one or other, or both, of the plasmids. Of 37 colonies of H2O9 cultured from one of these matings, 16 had acquired the Col Ib plasmid of FI2O, three the ColV plasmid and two had both plasmids. When the $\mathrm{K}^{-}$form of $\mathrm{H} 209$ was used as recipient, $\mathrm{I} 3$ of 34 colonies cultured had acquired $\mathrm{Col} \mathrm{Ib}$ only and the remainder had either ColV or both plasmids. The Col plasmid status of the colonies could easily be ascertained by spot-inoculating them on to 'lawns' of $E$. coli K I $2, \mathrm{KI}_{2} \mathrm{Col} \mathrm{Ib}^{+}$and $\mathrm{KI} 2 \mathrm{Col} \mathrm{V}^{+}$ on nutrient agar. Neither plasmid was completely stable in $\mathrm{H}_{209}$, and $\mathrm{Col}^{-}$forms could be obtained without difficulty from $\mathrm{Col}^{+}$forms; these $\mathrm{Col}^{-}$forms were devoid of transfer factors. The transfer factors of the ColV plasmid were classed as $\mathrm{fi}^{+}$, although one of 
Table 7. The lethality for mice of forms of E. coli $\mathrm{H} 209$ that had acquired the Col $V$ or Ib plasmids of E. coli $\mathrm{FI} 20$

$\begin{array}{lc}\begin{array}{c}\text { Form of } \mathrm{H} 209 \\ \text { administered }\end{array} & \begin{array}{c}\text { No. of } \\ \text { mouse deaths }\end{array} \\ \mathrm{ColV}^{+} & 68 \\ \mathrm{Col} \mathrm{Ib}^{+} & 47 \\ \mathrm{Col}^{-}(\mathrm{Col} \mathrm{V})^{*} & 33\end{array}$

* ColV plasmid and transfer factor acquired during mating with FI 20, then lost. Each of a group of 100 mice was given i.p. $5 \times 10^{7}$ viable organisms.

$50 \mathrm{ColV}^{-}$colonies of $E$. coli KI2 obtained from one mixed culture of this strain and $\mathrm{H}_{20} \mathrm{ColV}^{+}$was fully susceptible to the MS2 phage; the other 49 were $\mathrm{Tra}^{-}$.

The transfer of Collb and ColV from E. coli FI 20 to other strains of E. coli: its effect on the lethality of these strains for chickens and mice

Chickens, 2 weeks old, were injected i.v. with $\mathrm{Col}^{+}$and $\mathrm{Col}^{-}$forms of $E$. coli $\mathrm{H} 209$, PIO and KI2, obtained from matings of these strains with $E$. coli FI 20 or with strains to which the ColIb and ColV plasmids of FI20 had been transferred. In these (Table 6) and subsequent infection experiments a suitably high mortality rate was achieved by using 2-weekold in place of $3 \frac{1}{2}$-week-old chickens, and by substituting soft agar cultures, with their higher bacterial content, for broth cultures of the E. coli KI 2 and PIO strains. Most deaths occurred $\mathrm{I}$ to 3 days after inoculation, no characteristic lesions being noted at autopsy. All the strains acquiring the Col V plasmid of FI20, but not its Ib plasmid, were more lethal than the $\mathrm{Col}^{-}$strains from which they were derived. Also, loss of Col V from the H209 strain was accompanied by loss in lethality, while the acquisition of only the transfer factor of Col V by $E$. coli KI 2 was not accompanied by a significant increase in lethality. The increased lethality associated with possession of the ColV plasmid was still exhibited by the last recipient after six successive transfers between KI 2 strains. Several other $\mathrm{Col}^{-}, \mathrm{Col} \mathrm{Ib}^{+}$and $\mathrm{Col} \mathrm{V}^{+}$forms of E. coli $\mathrm{H} 209$ and $\mathrm{KI} 2$ obtained from other matings of these strains with F 20 were also tested in smaller groups of chickens; the results were similar to those in Table 6.

Mice were inoculated i.p. with forms of E. coli $\mathrm{H} 209$ that had or had not acquired the $\mathrm{Col} V$ or Ib plasmids of $E$. coli FI20 (Table 7). The mortality rate in the group given the $\mathrm{ColV}^{+}$form was much higher than in that given the $\mathrm{Col}^{-}$form $(P<0.00 \mathrm{I})$; mortality in the group given the $\mathrm{ColIb}^{+}$form was only slightly higher $(0.05<P<0 . \mathrm{I})$. In all, of I 30 mice given the $\mathrm{ColV}^{+}$form, 92 died; of 130 mice given the $\mathrm{ColV}^{-}$form, 38 died.

\section{The transfer of Col $V$ and other Col plasmids from enterobacterial strains to $E$. coli $\mathrm{K} 12$ : its effect on the lethality of the KI2 strain for chickens}

Groups of 30 two-week-old chickens were injected i.v. with a strain of E. coli KI 2 to which had been transferred $\mathrm{ColV}$ and other $\mathrm{Col}$ plasmids from enterobacterial strains (Table 8). Apart from differing in other respects, all seven ColV donor strains were epidemiologically unrelated; six had been isolated from cases of bacteraemia (two in humans and four in chickens), and one had been isolated from the faeces of a healthy pig. Four of these donor strains possessed transmissible Col plasmids in addition to Col V, and these co-transferred with ColV to the KI 2 strain. The KI 2 strains possessing plasmids similar, in the main, to the additional plasmids possessed by the four donor strains were included in the tests principally to determine whether the presence of the additional plasmids 
Table 8. The lethality for chickens of an E. coli $\mathrm{K} \mathrm{I} 2$ strain that had acquired $\mathrm{Col} \mathrm{V}$ and other plasmids from different enterobacterial strains

Plasmids acquired
by the KI 2 strain
under test
ColV, ColEI, Col Ia
ColV, Colla
ColV, ColIa
ColV, ColIb
ColV
ColV
ColV
ColEI, ColIa
ColIa
ColIb
ColI
ColEI
ColEI $\left(\mathrm{F}^{+}\right)^{*}$
ColEI $\left(\mathrm{F}^{-}\right)^{*}$
F
None

\begin{tabular}{|c|c|}
\hline Plasmid donor strains & $\begin{array}{l}\text { No. of deaths } \\
\text { following } \\
\text { infection with } \\
\text { the KI } 2 \text { straint }\end{array}$ \\
\hline E. coli $\mathrm{H} 26 \mathrm{I}$ & 27 \\
\hline E. coli $\mathrm{H} 247$ & 27 \\
\hline E. coli F157 & 26 \\
\hline E. coli F107 & 21 \\
\hline E. coli FI20 & 26 \\
\hline E. coli $\mathrm{P} 72$ & 27 \\
\hline E. coli $\mathrm{F} 70$ & 25 \\
\hline Paracolon & 5 \\
\hline Paracolon & 2 \\
\hline E. coli $\mathrm{F} 120$ & 2 \\
\hline $\begin{array}{l}\text { Salm. typhimurium } \\
\text { (Meynell, I968) }\end{array}$ & 4 \\
\hline E. coli FIO5 & 1 \\
\hline $\begin{array}{l}\text { E. coli } \mathrm{B} 165 \text { and } \\
\mathrm{K}_{1} 2 \mathrm{~F}^{+}\end{array}$ & 4 \\
\hline E. coli В 165 & 4 \\
\hline E. coli $\mathrm{KI} 2 \mathrm{~F}^{+}$ & I \\
\hline$\ldots$ & 3 \\
\hline
\end{tabular}

* The non-transferring ColEI plasmid of E. coli B1 65 had been transferred to the $\mathrm{K} 12$ strain by transfer factor $\mathrm{F}$; the EI $\left(\mathrm{F}^{+}\right)$strain had also acquired $\mathrm{F}$ but the EI $\left(\mathrm{F}^{-}\right)$strain had not.

$\dagger$ Two-week-old chickens, 30 group, each received i.v. $3.0 \times 10^{9}$ viable organisms from soft agar cultures. Strains isolated from human beings have the prefix $\mathbf{H}$; from chickens, F; from cattle, B; and from pigs, $\mathbf{P}$.

in the four strains influenced their pathogenicity. The $\mathrm{KJ}_{2} \mathrm{~F}^{+}$strain was tested mainly because the two forms of the KI2 strain that had received ColV plasmids from E. coli F7O and $\mathbf{P 7 2}$ had become, as a result, fully susceptible to the MS2 phage, indicating that their transfer factor was probably $\mathrm{F}$. The seven forms of the KI 2 strain acquiring Col $\mathrm{V}$ plasmids from the different $E$. coli strains had similar virulence for chickens and this was significantly higher than that of the KI 2 strain itself or its forms with other Col plasmids or F.

Mice in groups of 60 were each inoculated i.p. with $5 \times 10^{7}$ viable organisms of $E$. coli H209 or with forms of this strain that had acquired the ColI, Ia, Ib (from E. coli FI07, not FI 20) and the ColEI plasmids listed in Table 8; there was no significant difference between the mortality rate in the groups given the $\mathrm{Col}^{+}$forms of $\mathrm{H} 209$ and the group given the $\mathrm{H} 209$ strain itself.

During the search for the wild $\mathrm{ColV}^{+} E$. coli strains used in the above experiments, 179 bacteraemia strains of $E$. coli were examined for colicine production. Of 38 human strains, seven produced colicine $\mathrm{V}$ and eight produced other kinds of colicine. The corresponding proportions were: for $\mathrm{I} 2$ bovine strains, five with $\mathrm{ColV}$ and three with other colicines; for I 2 sheep strains, three with ColV and three with other colicines; and for II 7 chicken strains, 78 with ColV and 18 with other colicines.

The lethality for chickens of sterile preparations of cultures of Col $V^{+}$E. coli

Ultrasonicates of bacterial suspensions expressed from soft agar cultures of $\mathrm{Col}^{+}$forms of $E$. coli KI 2 and $\mathrm{H} 209$ and rendered organism-free by membrane filtration were injected i.v. in $5 \mathrm{ml}$ amounts, into eight 2-week-old chickens; none died. No deaths occurred in 
Table 9. Recovery of viable organisms from the blood and livers of chickens at intervals after inoculation of $\mathrm{Col}^{+}$or $\mathrm{ColV}^{-}$forms of E. coli $\mathrm{KI} 2$

\begin{tabular}{|c|c|c|c|c|c|}
\hline \multirow[b]{3}{*}{$\begin{array}{c}\text { Form } \\
\text { inoculated }\end{array}$} & \multirow[b]{3}{*}{$\begin{array}{c}\text { Chicken } \\
\text { no. }\end{array}$} & \multicolumn{4}{|c|}{$10^{-5} \times$ No. of organisms $/ \mathrm{ml}$, in: } \\
\hline & & \multicolumn{3}{|c|}{ Blood at } & \multirow{2}{*}{$\begin{array}{c}\text { Liver a } \\
24 \mathrm{~h}\end{array}$} \\
\hline & & $3 \mathrm{~h}$ & $6 \mathrm{~h}$ & $24 \mathrm{~h}$ & \\
\hline \multirow[t]{5}{*}{$\mathrm{ColV}^{+}$} & I & 170 & 200 & I500 & 5200 \\
\hline & 2 & 580 & 480 & 1200 & 1000 \\
\hline & 3 & 300 & 500 & 600 & 2200 \\
\hline & 4 & 300 & 450 & 280 & 6500 \\
\hline & 5 & 300 & 400 & 200 & 570 \\
\hline \multirow[t]{5}{*}{$\mathrm{ColV}^{-}$} & 6 & 300 & 100 & 27 & 1200 \\
\hline & 7 & 400 & 300 & 18 & 1500 \\
\hline & 8 & 450 & 300 & 15 & 170 \\
\hline & 9 & 150 & 150 & 4 & 450 \\
\hline & 10 & 170 & 80 & 2 & 400 \\
\hline
\end{tabular}

For each form, doses of $3.0 \times 10^{9}$ viable organisms were inoculated i.v. into groups of 5 two-week-old chickens which were killed $24 \mathrm{~h}$ later.

any of 14 chickens injected i.v. with $5 \mathrm{ml}$ volumes of broth cultures of these strains killed either by chloroform or by incubation at $37^{\circ} \mathrm{C}$ for $4 \mathrm{~h}$ after addition of $100 \mu \mathrm{g}$ neomycin $/ \mathrm{ml}$ culture. The $\mathrm{Col}^{+}$organisms employed in these and in subsequent experiments had acquired their ColV plasmid from E. coli FI20.

\section{The concentration of $\mathrm{ColV}^{+}$and $\mathrm{Col}^{-}$organisms in the tissues of infected chickens and mice}

The blood and liver concentrations of $\mathrm{Col}^{+}$and $\mathrm{ColV}^{-}$organisms at intervals after i.v. injection of chickens were estimated (Table 9). So was the ratio of $\mathrm{ColV}^{+}$and $\mathrm{ColV}^{-}$ organisms, and sometimes col $\mathrm{Vr}^{\mathrm{r}}$ organisms (colicine $\mathrm{V}$-resistant mutants), determined in chickens receiving mixtures of equal numbers of organisms (Table 10). In both experiments, higher concentrations of $\mathrm{ColV}^{+}$than of $\mathrm{ColV}^{-}$organisms or, where applicable, of $c o l \mathrm{~V}^{\mathrm{r}}$ organisms, were usually found in the blood - especially $24 \mathrm{~h}$ after inoculation. Slightly higher concentrations of $\mathrm{ColV}^{+}$than of the other organisms were sometimes found in the liver. In similar experiments in mice, higher concentrations of $\mathrm{ColV}^{+}$than of $\mathrm{ColV}^{-}$ organisms of $E$. coli $\mathrm{H} 209$ were found in the peritoneal fluid and blood $\mathrm{I} 8 \mathrm{~h}$ after i.p. injection (Tables II and I2).

The results of giving mixtures of organisms to chickens and mice might have been influenced by colicine $\mathrm{V}$ production and/or by ColV transfer occurring in vivo. The possibility in broth suspensions of colicine production by $\mathrm{ColV}^{+}$organisms suppressing Col $\mathrm{V}^{-}$ organisms and/or of ColV transfer was assessed; io $\mathrm{ml}$ volumes of broth were inoculated with $0.1 \mathrm{ml}$ amounts of broth cultures of $\mathrm{Col} \mathrm{V}^{+}$and $\mathrm{ColV}^{-}$organisms of E. coli $\mathrm{H} 209$ and incubated at $37^{\circ} \mathrm{C}$ for $24 \mathrm{~h}$. Of 100 colonies sampled from this mixture, 58 were $\mathrm{ColV}^{+}$ at $\mathrm{o} h$ and 50 were $\mathrm{ColV}^{+}$at $24 \mathrm{~h}$. In a similar experiment with $\mathrm{Col}^{+}$(nalidixic acidresistant mutants) and $\mathrm{ColV}^{-}$(ampicillin resistant) organisms of E. coli KI2, 39 of the roo colonies obtained from the mixed culture at o h were $\mathrm{Col} \mathrm{V}^{+}$; at $24 \mathrm{~h}_{49} \mathrm{Col} \mathrm{V}^{+}$were obtained, the slight increase probably being accounted for by the fact that eight of the 49 colonies consisted of $a m p^{r}$ organisms that had acquired the ColV plasmid. 
Table 10. The ratio of $\mathrm{ColV}^{+}, \mathrm{ColV}^{-}$and col $\mathrm{V}^{*}$ organisms of E. coli strains $\mathrm{H}_{209}$ or $\mathrm{K} 12$ in the blood and livers of chickens at intervals after inoculation of equal numbers of these organisms

\begin{tabular}{|c|c|c|c|c|c|}
\hline \multirow{2}{*}{$\begin{array}{l}\text { Organisms } \\
\text { inoculated }\end{array}$} & \multirow{2}{*}{$\begin{array}{l}\text { Time after } \\
\text { inoculation }(\mathrm{h})\end{array}$} & \multirow{2}{*}{$\begin{array}{l}\text { Tissue } \\
\text { examined }\end{array}$} & \multicolumn{3}{|c|}{ No. of colonies $\uparrow$ that were: } \\
\hline & & & $\mathrm{ColV}^{+}$ & $\mathrm{ColV}^{-}$ & colv $\mathrm{V}^{\mathrm{r}}$ \\
\hline $\begin{array}{l}\mathrm{ColV}^{+} \text {and } \mathrm{ColV}^{-} \text {forms } \\
\text { of } \mathrm{H}_{209}\end{array}$ & $\begin{array}{l}0.05 \\
3 \\
6 \\
24 \\
24\end{array}$ & $\begin{array}{l}\text { Blood } \\
\text { Blood } \\
\text { Blood } \\
\text { Blood } \\
\text { Liver }\end{array}$ & $\begin{array}{r}90 \\
113 \\
117 \\
150 \\
104\end{array}$ & $\begin{array}{r}60 \\
37 \\
33 \\
0 \\
46\end{array}$ & $\begin{array}{l}- \\
\bar{z} \\
-\end{array}$ \\
\hline $\begin{array}{l}\mathrm{ColV}^{+} \text {and } \mathrm{ColV}^{-} \text {forms } \\
\text { of } \mathrm{KI} 2\end{array}$ & $\begin{array}{l}0.05 \\
3 \\
6 \\
24 \\
24\end{array}$ & $\begin{array}{l}\text { Blood } \\
\text { Blood } \\
\text { Blood } \\
\text { Blood } \\
\text { Liver }\end{array}$ & $\begin{array}{r}78 \\
114 \\
118 \\
141 \\
92\end{array}$ & $\begin{array}{r}72 \\
36 \\
32 \\
9 \\
58\end{array}$ & $\begin{array}{l}- \\
z \\
-\end{array}$ \\
\hline $\begin{array}{l}\mathrm{ColV}^{+}, \mathrm{ColV}^{-} \text {and } \mathrm{col}^{\mathrm{r}} \\
\text { forms of } \mathrm{KI} 2\end{array}$ & $\begin{array}{l}0.05 \\
3 \\
6 \\
24 \\
24\end{array}$ & $\begin{array}{l}\text { Blood } \\
\text { Blood } \\
\text { Blood } \\
\text { Blood } \\
\text { Liver }\end{array}$ & $\begin{array}{r}39 \\
90 \\
97 \\
134 \\
60\end{array}$ & $\begin{array}{r}55 \\
23 \\
23 \\
1 \\
36\end{array}$ & $\begin{array}{l}56 \\
37 \\
30 \\
15 \\
54\end{array}$ \\
\hline
\end{tabular}

* $c o l \mathrm{~V}^{\mathrm{r}}=$ colicine $\mathrm{V}$-resistant mutants of E. coli $\mathrm{K} 12$.

$\dagger$ Three chickens were inoculated i.v. with mixtures of $2 \times 10^{8}$ washed viable organisms of each pair or trio of strains; 50 colonies from each chicken sample were tested (i.e. I 50 in all).

Table I I. Viable numbers of organisms in the peritoneal washings and blood of mice I $8 \mathrm{~h}$ after inoculation with ColV $\mathrm{V}^{+}$or ColV-forms of E. coli $\mathrm{H} 209$

\begin{tabular}{|c|c|c|c|}
\hline \multirow[b]{2}{*}{$\begin{array}{c}\text { Form } \\
\text { inoculated }\end{array}$} & \multirow[b]{2}{*}{$\begin{array}{c}\text { Mouse } \\
\text { no. }\end{array}$} & \multicolumn{2}{|c|}{$10^{-3} \times$ no. of organisms $/ \mathrm{ml}$ of } \\
\hline & & $\begin{array}{l}\text { Peritoneal } \\
\text { washings* }\end{array}$ & Blood \\
\hline \multirow[t]{6}{*}{$\mathrm{ColV}^{+}$} & I & 2000000 & 15000 \\
\hline & 2 & 8000000 & 10000 \\
\hline & 3 & 2500000 & 10000 \\
\hline & 4 & 2500000 & 6000 \\
\hline & 5 & 2000000 & 1000 \\
\hline & 6 & 3000000 & 600 \\
\hline \multirow[t]{6}{*}{$\mathrm{ColV}^{-}$} & 7 & 700000 & I 250 \\
\hline & 8 & 7500 & 100 \\
\hline & 9 & 2000 & 2 \\
\hline & 10 & I 750000 & I \\
\hline & II & 15 & $<\mathrm{I}$ \\
\hline & I 2 & 5 & $<\mathrm{I}$ \\
\hline
\end{tabular}

For each form, doses of $5 \times 10^{7}$ viable organisms were inoculated i.p. into groups of 6 mice.

* The peritoneal washings were obtained by rinsing out the abdomen with $\mathrm{I} \mathrm{ml}$ saline.

The survival of $\mathrm{ColV}^{+}$and Col $\mathrm{V}^{-}$organisms in chicken serum

Fresh samples of serum, each taken from a different healthy 4-week-old chicken, were inoculated with mixtures of diluted broth cultures of $\mathrm{Col}^{+}$and $\mathrm{Col} \mathrm{V}^{-}$or col $\mathrm{V}^{\mathrm{r}}$ organisms of $E$. coli KI2 and $\mathrm{H} 209$ and incubated at $37^{\circ} \mathrm{C}$. The ratio of the two kinds of organism in each sample was determined at the start and at the time when the bacterial concentration had decreased by more than $90 \%$ (Table I3). The Col $\mathrm{V}^{+}$organisms of $E$. coli $\mathrm{KI} 2$ survived much better in all six samples than did the Col $\mathrm{V}^{-}$or col $\mathrm{V}^{\mathrm{r}}$ organisms. A similar trend was 
Table I2. The ratio of $\mathrm{ColV}^{+}$and $\mathrm{Col} \mathrm{V}^{-}$organisms of E. coli $\mathrm{H} 209$ in the peritoneal washings and blood of mice $18 \mathrm{~h}$ after inoculation of equal numbers of both organisms

$\begin{array}{ccc}\begin{array}{c}\text { No. of Col } \mathrm{V}^{+} \text {colonies } \\ \text { Mongst I0o colonies } \\ \text { Mouse } \\ \text { no. }\end{array} & \begin{array}{c}\text { Peritoneal } \\ \text { washings }\end{array} & \text { Blood } \\ 1 & 100 & 100 \\ 2 & 100 & 100 \\ 3 & 100 & 100 \\ 4 & 100 & 99 \\ 5 & 100 & 98 \\ 6 & 100 & 98 \\ 7 & 100 & 97 \\ 8 & 92 & 100\end{array}$

Doses of $2.5 \times 10^{7}$ viable organisms of both strains were inoculated i.v. into each of 8 mice which were killed $18 \mathrm{~h}$ later.

Table I3. The comparative survival of $\mathrm{ColV}^{+}, \mathrm{ColV}^{-}$and colV $\mathrm{V}^{\mathrm{r}}$ organisms of E. coli $\mathrm{K} \mathrm{I} 2$ or $\mathrm{H} 209$ in samples of chicken serum inoculated with mixtures of these organisms

\begin{tabular}{|c|c|c|c|}
\hline \multirow{2}{*}{$\begin{array}{l}\text { Serum samples } \\
\text { inoculated with } \\
\text { organisms of }\end{array}$} & \multirow{2}{*}{$\begin{array}{l}\text { No. of } \\
\text { serum } \\
\text { sample }\end{array}$} & \multicolumn{2}{|c|}{$\begin{array}{l}\text { No. of Col } \mathrm{V}^{+} \text {colonies } \\
\text { among } 50 \text { colonies } \\
\text { cultured at: }\end{array}$} \\
\hline & & oh & $\mathrm{I}-2 \mathrm{~h}^{*}$ \\
\hline \multirow[t]{6}{*}{$\mathrm{ColV}^{+}$and $\mathrm{ColV}^{-} \mathrm{K} 12$} & I & 21 & 35 \\
\hline & 2 & $2 I$ & 44 \\
\hline & 3 & $2 I$ & 48 \\
\hline & 4 & $2 \mathrm{I}$ & 46 \\
\hline & 5 & $2 \mathrm{I}$ & $4 I$ \\
\hline & 6 & 21 & 43 \\
\hline \multirow{6}{*}{$\mathrm{ColV}^{+}$and $c o l \mathrm{~V}^{\mathrm{r}} \mathrm{KI2}$} & I & 14 & 45 \\
\hline & 2 & 14 & 42 \\
\hline & 3 & I4 & 40 \\
\hline & 4 & I4 & 34 \\
\hline & 5 & I4 & 39 \\
\hline & 6 & 14 & 32 \\
\hline \multirow[t]{6}{*}{$\mathrm{ColV}^{+}$and $\mathrm{Col} \mathrm{V}^{-} \mathrm{H} 209$} & I & 23 & 34 \\
\hline & 2 & 23 & 45 \\
\hline & 3 & 23 & 46 \\
\hline & 4 & 23 & 39 \\
\hline & 5 & 23 & 39 \\
\hline & 6 & 23 & 45 \\
\hline
\end{tabular}

* At this time the concentration of viable organisms was $<10 \%$ of the approx. $10^{4} / \mathrm{mll}^{7}$ present at o h.

noted for the $\mathrm{ColV}^{+}$and $\mathrm{ColV}^{-}$organisms of E. coli $\mathrm{H} 209\left(\mathrm{Col} \mathrm{V}^{+}\right.$and $\mathrm{Col} \mathrm{V}^{-}$organisms of $\mathrm{KI} 2$ and $\mathrm{H} 209$ survived equally well as mixtures in one of the serum samples that had been heated to $65{ }^{\circ} \mathrm{C}$ for $30 \mathrm{~min}$, the concentration of both kinds of organisms increasing about tenfold during a $3 \mathrm{~h}$ incubation period).

Next, serum samples were inoculated with either $\mathrm{ColV}^{+}$or $\mathrm{ColV}^{-}$organisms of $E$. coli $\mathrm{KI} 2$. The concentration of viable $\mathrm{ColV}^{-}$organisms in the six samples decreased by 99 to $100 \%$ (median $99.5 \%$ ) during $\mathrm{I} \mathrm{h}$ incubation, whereas the concentration of viable $\mathrm{Col} \mathrm{V}^{+}$ 
organisms decreased by only 94.5 to $99 \%$ (median $97.5 \%$ ); for any particular sample of serum, the concentration of surviving $\mathrm{ColV}^{-}$organisms at this time was 3 to $\mathrm{I} 2$ times less than that of $\mathrm{Col} \mathrm{V}^{+}$organisms.

\section{Agglutination tests between $\mathrm{ColV}^{+}$and $\mathrm{ColV}^{-}$organisms and antisera}

Antisera were prepared against $E$. coli FI2O and against forms of $E$. coli H2O9 and KI 2 with and without the ColV plasmid of FI 20. These five antisera were then employed in tube O agglutination tests against FI 20 and forms of E. coli $\mathrm{H} 209$, E. coli PI 3 and Shigella sonnei both with and without the ColV plasmid of FI20; E. coli KI2 organisms were not employed because of their rough nature. The tests were repeated by the slide method using live bacterial suspensions. None of the strains that had acquired the ColV plasmid of FI 20 had acquired an antigen by these tests.

\section{DISCUSSION}

The results indicate that the specific toxic activity of $E$. coli 55 is controlled by a transmissible plasmid designated, provisionally, Vir. Because of its high susceptibility to heat and low $\mathrm{pH}$ and its failure to dialyse, the toxin is probably protein in nature. Furthermore, the agglutination of $\mathrm{Vir}^{+}$organisms by specific antiserum suggests that Vir may be a surface antigen. If so, it is not an internationally recognized one (I. Ørskov, W.H.O. Escherichia coli Centre, Copenhagen, personal communication). Although the organisms were agglutinated, their toxic activity was not neutralized by antiserum because pretreated culture filtrates and ultrasonicates were fully lethal for experimental animals. This, of course, is not an unusual phenomenon - some endotoxins, for example, resemble Vir in this respect. Even so, the possibility that the apparent identity of the agglutinogen and the toxin of $\mathrm{Vir}^{+}$ organisms is merely a reflexion of two different genes being located on the same plasmid cannot be entirely overlooked.

$\mathrm{Vir}^{+}$strains of $E$. coli appear to be uncommon in nature, only two strains being found amongst the 190 examined from man and domestic animals; both were isolated from sheep, which are rarely given antibiotics orally. Had the Vir plasmid originated in the $E$. coli flora of a species of domestic animal frequently given antibiotics orally, e.g. pigs, the plasmid might well have become more common because its transfer factor can transfer antibiotic resistance determinants in addition to the Vir determinant.

Although ultrasonicates and culture filtrates of $\mathrm{Vir}^{+}$organisms were lethal for experimental animals, especially chickens, toxin production was not detected, for example, under anaerobic or partially anaerobic conditions. The question arises whether toxin is produced in significant amounts in vivo. Certainly the acquisition of the Vir plasmid by the Salm. typhimurium strain did not lower the survival rate of infected chicks, possibly because of the comparative instability of the plasmid in this particular strain.

In all the transfer experiments involving the ColV plasmid of E. coli FI20, including that of six consecutive transfers from one strain of $E$. coli $\mathrm{K} I 2$ to another, the subsequent animal inoculation studies revealed that the acquisition of ColV was always accompanied by an increase in lethality. This was not so with strains that had apparently only acquired the transfer factor of the ColV plasmid or that had only acquired the ColIb plasmid of FI 20. Also, spontaneous loss of the ColV plasmid by a recipient strain was accompanied by a return to normal lethality. Thus it seems likely that the genetic elements responsible for this increased lethality and for colicine V production in FI 20 are located on the same plasmid. The subsequent observation of lethality increase on transfer of ColV plasmids to E. coli KI 2 from another six wild $\mathrm{Col} \mathrm{V}^{+}$strains of $E$. coli, that differed widely in their origins, indicates 
that there is a general association between the genes for increased lethality and those for colicine $\mathrm{V}$ production. In fact, colicine $\mathrm{V}$ itself may well be responsible for the increased lethality of the organisms that produce it.

Heatley \& Florey (1946) and Braude \& Siemienski (I964, 1965) found purified preparations of colicine V to be non-toxic for mice. Preparations used by Hutton and Goebel (I96I), however, were toxic, but it is possible that the $\mathrm{O}$ antigen which their preparations still contained might have accounted for this. The results of the agglutination tests in the present studies indicate that genes controlling $O$ antigen production in FI2O had not been transferred with those controlling colicine $\mathrm{V}$ production. Also, the large doses of ultrasonicates, culture filtrates and dead bacteria of $\mathrm{Col} \mathrm{V}^{+}$recipient strains given to chickens were harmless. It therefore seems improbable that the increased lethality of the $\mathrm{Col}^{+}$strains was due to a direct toxic effect.

The recovery pattern of $\mathrm{ColV}^{+}$and $\mathrm{ColV}^{-}$organisms in chickens or mice revealed that the $\mathrm{ColV}^{+}$organisms survived better in, or were removed less rapidly from, the blood and peritoneal fluids than the $\mathrm{ColV}^{-}$organisms. This may well be the reason for their greater lethality. The bactericidal activity of serum is probably involved to some degree because $\mathrm{Col} \mathrm{V}^{+}$organisms survived better than the corresponding $\mathrm{Col} \mathrm{V}^{-}$organisms in chicken serum in the in vitro tests.

Whether or not the increased lethality possessed by $\mathrm{Col} \mathrm{V}^{+}$organisms is indeed due to the colicine they produce cannot be decided. However, from the practical point of view, colicine $\mathrm{V}$ production, at least when plasmid-controlled, should be regarded as a pathogenic characteristic. It is noteworthy that production of this colicine was a common feature of strains of $E$. coli associated with bacteraemia in man and domestic animals.

I am grateful to Mr M. Huggins for his capable technical help. My thanks are also due to Miss Doreen Cooper, Professor P. Fredericq, Dr R. F. Gordon, Mrs Anne Millington, Dr Ida Ørskov and Mrs Zöe Parsell for assistance in a variety of ways.

Note added in proof. Four of 30 antibiotic sensitive $078: \mathrm{K} 80$ strains of $E$. coli isolated from calves with bacteraemia have been found to produce Vir. Although the four strains possessed transfer factors, it was only possible to transmit Vir from two of them.

\section{REFERENCES}

ANDERSON, E. S. (1965). A rapid screening test for transfer factors in drug-sensitive Enterobacteriaceae. Nature, London 208, 1016-1017.

Braude, A. I. \& Siemienski, J. S. (1964). Plasma bactericidal power of mice injected with non-toxic colicine V. Federation Proceedings 23, 565.

BRAude, A. I. \& SiemienSKi, J. S. (I965). The influence of bacteriocins un resistance to infection by Gramnegative bacteria. I. The effect of colicin on the bactericidal power of the blood. Journal of Clinical Investigation 44, 849-859.

Davis, J. E., Strauss, J. H., Jun. \& Sinsheimer, R. L. (196I). Bacteriophage MS2: another RNA phage. Science, New York 134, 1427.

Heatley, N. G. \& FloRey, H. W. (1946). An antibiotic from Bacterium coli. British Journal of Experimental Pathology 27, 378-390.

Hutton, J. J. \& Goebel, W. F. (I96I). Colicine V. Proceedings of the National Academy of Science of the United States of America 47, I498-1500.

LEWIS, M. J. (I968). Transferable drug resistance and other transferable agents in strains of Escherichia coli from two human populations. Lancet i, 1389-1393.

Meynell, G. G. (1968). Bacterial sex factors. In Annual Report of the Lister Institute for Preventive Medicine. 
Miles, A. A. \& MisRa, S. S. (1938). The estimation of the bactericidal power of the blood. Journal of Hygiene 38, 732-749.

ØRSKOV, I. \& ØRSKOV, F. (1966). Episome-carried surface antigen K88 of Escherichia coli. I. Transmission of the determinant of the K88 antigen and influence on the transfer of chromosomal markers. Journal of Bacteriology 9r, 69-75.

Skerman, F. J., Formal, S. B. \& Falkow, S. (1972). Plasmid-associated enterotoxin production in a strain of Escherichia coli isolated from humans. Infection and Immunity 5, 622-624.

Smith, H. Williams \& Halls, S. (I967). The transmissible nature of the genetic factor in Escherichia coli that controls haemolysin production. Journal of General Microbiology 47, 153-161.

Smith, H. Williams \& Halls, S. (1968). The transmissible nature of the genetic factor in Escherichia coli that controls enterotoxin production. Journal of General Microbiology 52, 319-334.

Smith, H. Williams \& LingGood, M. A. (1970). Transfer factors in Escherichia coli with particular regard to their incidence in enteropathogenic strains. Journal of General Microbiology 62, 287-299.

Smith, H. Williams \& Linggood, M. A. (1971). The transmissible nature of enterotoxin production in a human enteropathogenic strain of Escherichia coli. Journal of Medical Microbiology 4, 30I-305.

Smith, H. Williams \& LingGood, M. A. (1972). Further observations on Escherichia coli enterotoxin with particular regard to those produced by atypical piglet strains and by calf and lamb strains: the transmissible nature of these enterotoxins and of a $\mathrm{K}$ antigen possessed by calf and lamb strains. Journal of Medical Microbiology 5, 243-249. 